\title{
ESTRUTURA CRUSTAL DA BACIA DO PARANÁ COM INVERSÃO DE ONDAS DE SUPERFÍCIE E FUNÇÕES DO RECEPTOR
}

\author{
Meijian An \\ Orientador: Dr. Marcelo Sousa de Assumpção (IAG-USP) \\ 129 p - Tese (Doutorado) - Defesa 24.09.2004
}

RESUMO. Este trabalho é devotado ao estudo simultâneo das ondas de superfície e das funções do receptor por algoritmo de otimização não-linear, e aplicação à estrutura de velocidade de onda S na Bacia do Paraná, SE Brasil. As ondas de superfície são usadas principalmente para determinar estruturas da crosta (ou litosfera), e foram estudadas extensivamente pelo método linearizado e por algoritmos globais recentemente. Os estudos de dispersão de ondas de superfície são feitos geralmente com modelo 1-D horizontalmente homogêneo. Mas o percurso das ondas de superfície observadas sempre cruza províncias geológicas diferentes, e 0 modelo 1-D invertido é feito freqüentemente para representar uma média de estrutura ao longo do percurso. Testes sintéticos mostram que diferentes modelos de velocidade de ondas S podem ser obtidos dependendo da parametrização do modelo para alguns percursos com variações laterais fortes. Ou, se características muito diferentes e instáveis aparecem dentro dos modelos invertidos com parametrizações diferentes, forte variação lateral pode existir no percurso de propagação, e o modelo 1-D médio pode não representar as propriedades médias ao longo do percurso. As funções do receptor também são muito usadas para estudar a estrutura da crosta (ou litosfera), e foram estudadas extensivamente pelo método linearizado. Como a dispersão de onda de superfície e as funções do receptor são sensíveis a propriedades sísmicas diferentes, suas inversões multi-objetivos (ou conjuntas) podem fornecer vínculos melhores às interfaces das camadas e às velocidades de onda S. A inversão conjunta foi feita pelo método linearizado por outros autores. Usando o método linearizado em suas inversões respectivas ou conjuntas, a solução é somente uma tendência geral das velocidades de onda S. 0 algoritmo genético opera sobre uma população de soluções e pode processar muitas soluções em paralelo, servindo especialmente para problemas multi-objetivos. Recentemente, algoritmos genéticos competentes, superiores ao algoritmo genético convencional, foram propostos e podem resolver problemas difíceis rapidamente e com exatidão. Neste estudo, eu introduzi um dos algoritmos genéticos competentes, algoritmo de otimização bayesiano, para amostrar modelos ótimos diversos sob níveis aceitáveis. Os modelos escolhidos por critérios multi-objetivos mostraram a resolusão e a extensão das soluções nos espaços de objetivos e modelos. Os resultados das inversões de dispersão de ondas de superfície vinculadas por mais um objetivo (funções do receptor ou diferenças do tempo de Ps-P) são similares nas tendências gerais. As análises das ondas de superfície e as funções do receptor mostram que as velocidades de onda $S$ menores que 4,0 km/s na crosta inferior entre 20 e $40 \mathrm{~km}$ de profundidade, e 4,65 km/s em média nos primeiros $100 \mathrm{~km}$ do manto superior parecem ser características da Bacia do Paraná. Outros estudos indicaram resultados similares. Estes resultados podem indicar que a crosta inferior abaixo da Bacia do Paraná tem uma composição mais félsica comparada às faixas em torno dela. As profundidades médias da Moho têm aproximadamente $40-45 \mathrm{~km}$, consistentes com as estimativas da espessura da crosta de 40 a $46 \mathrm{~km}$ usando as funções do receptor.

ABSTRACT. This work is devoted to the simultaneous study of surface waves and receiver functions by nonlinear optimization algorithm and its application to the S-velocity structure in the Paraná Basin, SE Brazil. Surface waves are mainly used to study the crustal (or lithospheric) structure, and have been studied extensively by linearized method and global algorithms recently. The studies of surface wave dispersion are usually done with horizontally homogeneous model. But observed surface waves always cross different geological provinces, and the resulting 1-D model is often taken to represent an average of the structure along the path. Synthetic tests showed that different S-wave velocity models can be obtained depending on the model parameterization for a path with strong lateral variations. Or say, if different and unstable features are obtained in the inverted models by different parameterizations, strong lateral variation may be present in the propagation path, and the average 1-D model may not represent average properties along the path. Receiver functions are also used to study the crustal (or lithospheric) structure, and have been studied extensively by linearized method. Because surface wave dispersion and receiver functions are sensitive to different, seismic properties, their multi-objective (or joint) inversion can provide tighter constraints on layer-interfaces and S-velocities. The joint inversion has been done by linearized method previously. Using the linearized method, the solution can only show the general S-velocity trend. Genetic algorithm operates on a population of solutions and can process a number of solutions in parallel, so it is particularly suited for multi-objective problems. Recently, some competent genetic algorithms, far superior to the conventional genetic algorithm, have been proposed and can solve hard problems quickly, reliably and accurately. In this study, I introduced one of the competent genetic algorithms, Bayesian optimization algorithm, to sample diverse optimal models under acceptable levels. The models chosen by multi-objective criteria showed the resolution and extent of the solutions in objective space and model-space areas. The results inverted by surface wave dispersion with the constraint of Ps-P and by multi-objective optimization of surface waves and receiver functions are similar in the general trends. The results show that the S-velocity of the lower crust in the Paraná Basin is less than $4.0 \mathrm{~km} / \mathrm{s}$ between 20 and $40 \mathrm{~km}$ depth, and an average velocity of $4.65 \mathrm{~km} / \mathrm{s}$ in the top $100 \mathrm{~km}$ of the upper mantle seem to be characteristic of the basin. Other studies had indicated similar results. These results can indicate that the lower crust in the Paraná Basin has a more felsic composition compared with the neighour foldbelts. The average Moho depth is approximately $40-45 \mathrm{~km}$, which is consistent with the estimates of the crustal thickness $40-46 \mathrm{~km}$ in previous receiver function studies. 